\title{
31. DATA REPORT: BIOSTRATIGRAPHY OF EOCENE AND UPPER CRETACEOUS CHALKS FROM THE ERATOSTHENES SEAMOUNT REGION IN THE EASTERN MEDITERRANEAN ${ }^{1}$
}

\author{
T. Scott Staerker 2,3
}

\section{INTRODUCTION}

During Ocean Drilling Program (ODP) Leg 160, four sites were drilled along a south to north transect across the Eratosthenes Seamount in the Eastern Mediterranean Sea (Fig. 1). Because deep drilling of the Eratosthenes Seamount structure had not previously been conducted, the sediment and rock samples collected during Leg 160 are the sole sources of tangible geologic data regarding the composition and age of this dominant bathymetric feature. The oldest material suitable for nannofossil biostratigraphy, which consisted of middle to lower Eocene and upper Cretaceous chalks, was collected from Holes 966F and 967E (Emeis, Robertson, Richter, et al., 1996). A semiquantitative study of calcareous nannofossils from the Eocene and Cretaceous chalks from the Eratosthenes Seamount are detailed in this data report.

\section{SCIENTIFIC OBJECTIVES, METHODS, AND BIOSTRATIGRAPHIC ZONATIONS}

A total of 45 samples from Hole 966F and 86 samples from 967E were analyzed. Smear slides were prepared using material shaved from the interior part of core samples.

Taxa identifications were performed using a Zeiss Universal microscope at 1250x and 500x magnification. Species abundance estimates were made using a scale modified from Hay (1970). To graphically display the abundance characteristics of the studied species, each letter designation under Hay's scale for abundance was assigned a specific histogram bar size as shown on the individual range charts (Tables 1-4)

The zonation scheme of Okada and Bukry (1980) was used for biostratigraphic subdivisions of the middle and lower Eocene material. The zonation scheme of Roth (1978), as modified by Moshkovitz (1984), was used to classify the Cretaceous samples. The time scales, nannofossil zonation schemes, and age assignments for all datums used in this study are found in Figures 2 and 3.

Preservation was observed as either fair or poor. For this study, fair preservation describes samples in which dissolution and/or secondary overgrowth partially alter a specimens diagnostic morphological characteristics, but nearly all specimens' can be identified at the species level. Poor preservation describes samples in which severe dissolution, fragmentation, and/or secondary overgrowth is observed and primary features are largely destroyed.

\section{HOLE 966F}

Hole $966 \mathrm{~F}$ was drilled into the crest of the Eratosthenes Seamount. Of the five holes drilled at Site 966, only sediments from Hole

${ }^{1}$ Robertson, A.H.F., Emeis, K.-C., Richter, C., and Camerlenghi, A. (Eds.), 1998. Proc. ODP, Sci. Results, 160: College Station, TX (Ocean Drilling Program).

${ }^{2}$ Texas Microscopy, 4812 Hanover Drive, Flower Mound, TX 75028, U.S.A

${ }^{3}$ Present address: BP Exploration, PO Box 4587, Houston, TX 77210-4587, U.S.A
966F were older than Pliocene. Hole 966F was washed down through Pleistocene and Pliocene sediments to a depth of 58 meters below seafloor (mbsf), where lower Pliocene oozes and calcareous conglomerates were recovered using rotary coring. From 105 to 298 mbsf, biosparites, algal mudstones, and recrystallized limestones were recovered. The interval from 105 to $298 \mathrm{mbsf}$ did not contain nannofossils, but was interpreted to be Miocene in age (Emeis, Robertson, Richter, et al., 1996). Unconformably below the Miocene rocks, bituminous, calcareous mudstones containing middle Eocene nannofossils were observed in Core 160-966F-26R. Samples for calcareous nannofossil study were collected from Cores 160-966F-26R through to the bottom of the hole at Core $31 \mathrm{R}$. A range chart of species observed within this interval is shown in Table 1.

From Sample 160-966F-26R-1, 23-24 cm (298.53 mbsf), through 27R-1, 130-131 cm (309.20 mbsf), nannofossils interpreted to be within Subzone CP14b were observed. The typical assemblage from this interval contains Ericsonia formosa, Cribrocentrum reticulatum, Reticulofenestra umbilicus, Discoaster saipanensis, Discoaster barbadiensis, and Chiasmolithus grandis. Zonal markers Chiasmolithus solitus and Chiasmolithus oamaruensis are absent. Although it is not used as a primary zonal marker, the first appearance datum (FAD) of Helicosphaera compacta was observed in this zone at Sample 160966F-26R-4, 3-4 cm (301.88 mbsf). Preservation is fair throughout this interval; however, most specimens of Chiasmoliths are difficult to distinguish at the species level because of heavy overgrowths.

From Sample 160-966F-27R-2, 22-23 cm (309.54 mbsf), through 29R-1, 128-129 cm (328.28 mbsf), C. solitus was a rare part of the assemblage, which indicates that this sample is within Subzone CP $14 \mathrm{a}$. The FAD of $D$. saipanensis and $R$. umbilicus were observed in

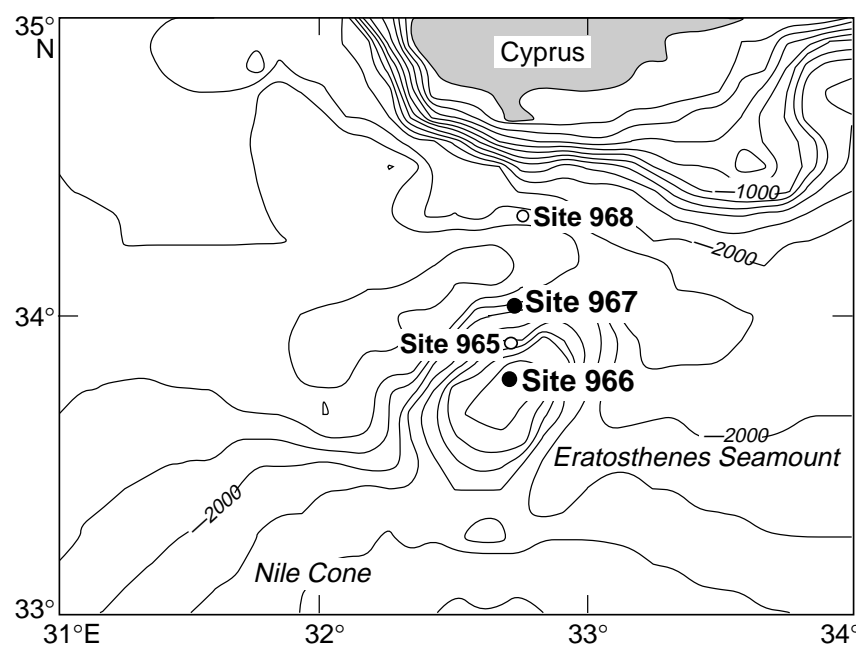

Figure 1. Location of drill sites along a south to north transect across the Eratosthenes Seamount in the Eastern Mediterranean. Bathymetry is in meters below sea level. 


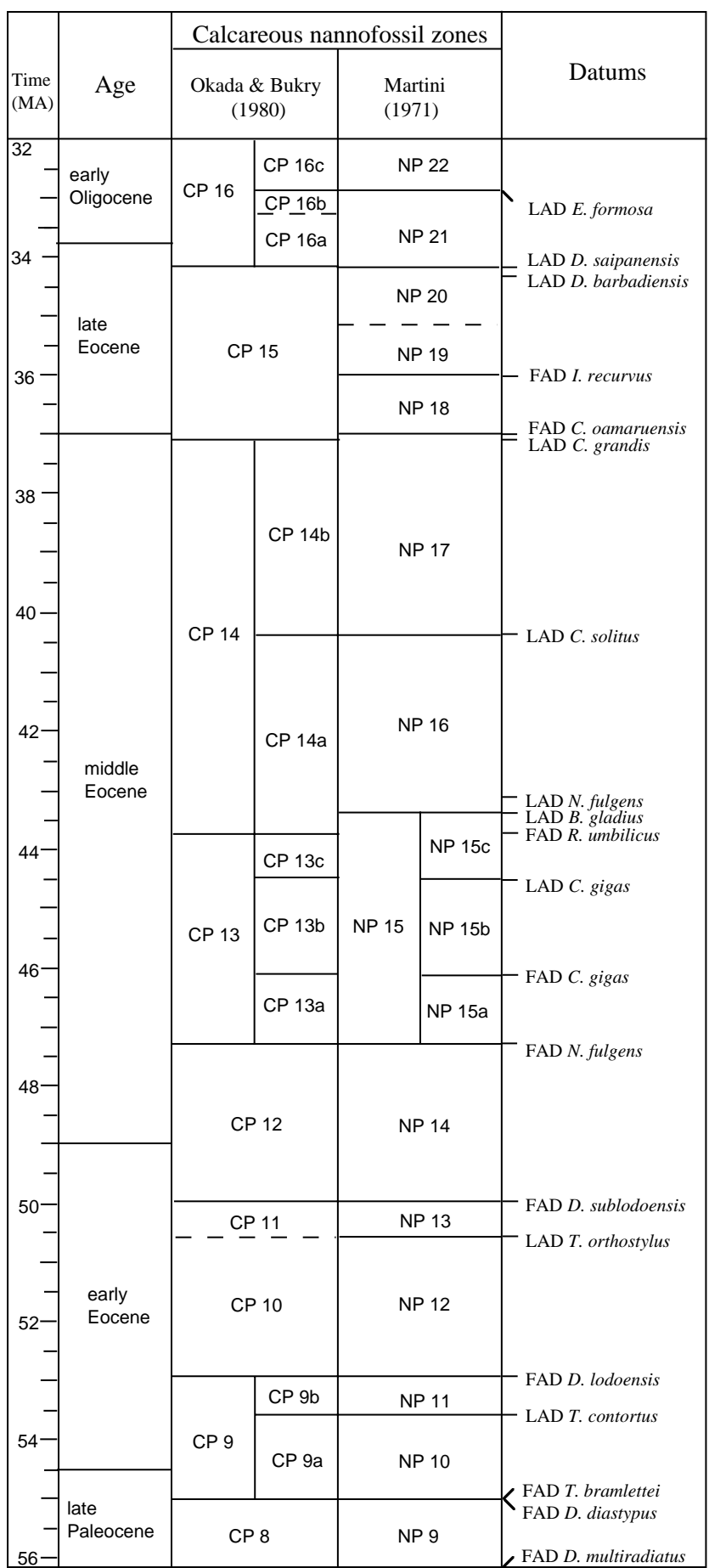

Figure 2. Time scale showing early Oligocene through late Paleocene calcareous nannofossil events (Berggren et al., 1995). FAD = first appearance datum; $\mathrm{LAD}=$ last appearance datum.

this interval. C. reticulatum was observed in only the upper eight samples of this interval.

Subzone CP13c was observed only in the two samples immediately below the FAD of $R$. umbilicus. Nannotetrina fulgens and Chiasmolithus gigas, which are used to subdivide Zone CP13, were not observed. In Sample 160-966F-29R-2, 134-135 cm (329.94 mbsf), several nannofossil events were recognized, including the FADs of Zygrhablithus bijugatus, Sphenolithus spiniger, and Calcidiscus protoannulus. In the next sample downhole (at $330.43 \mathrm{mbsf}$ ), the last ap-

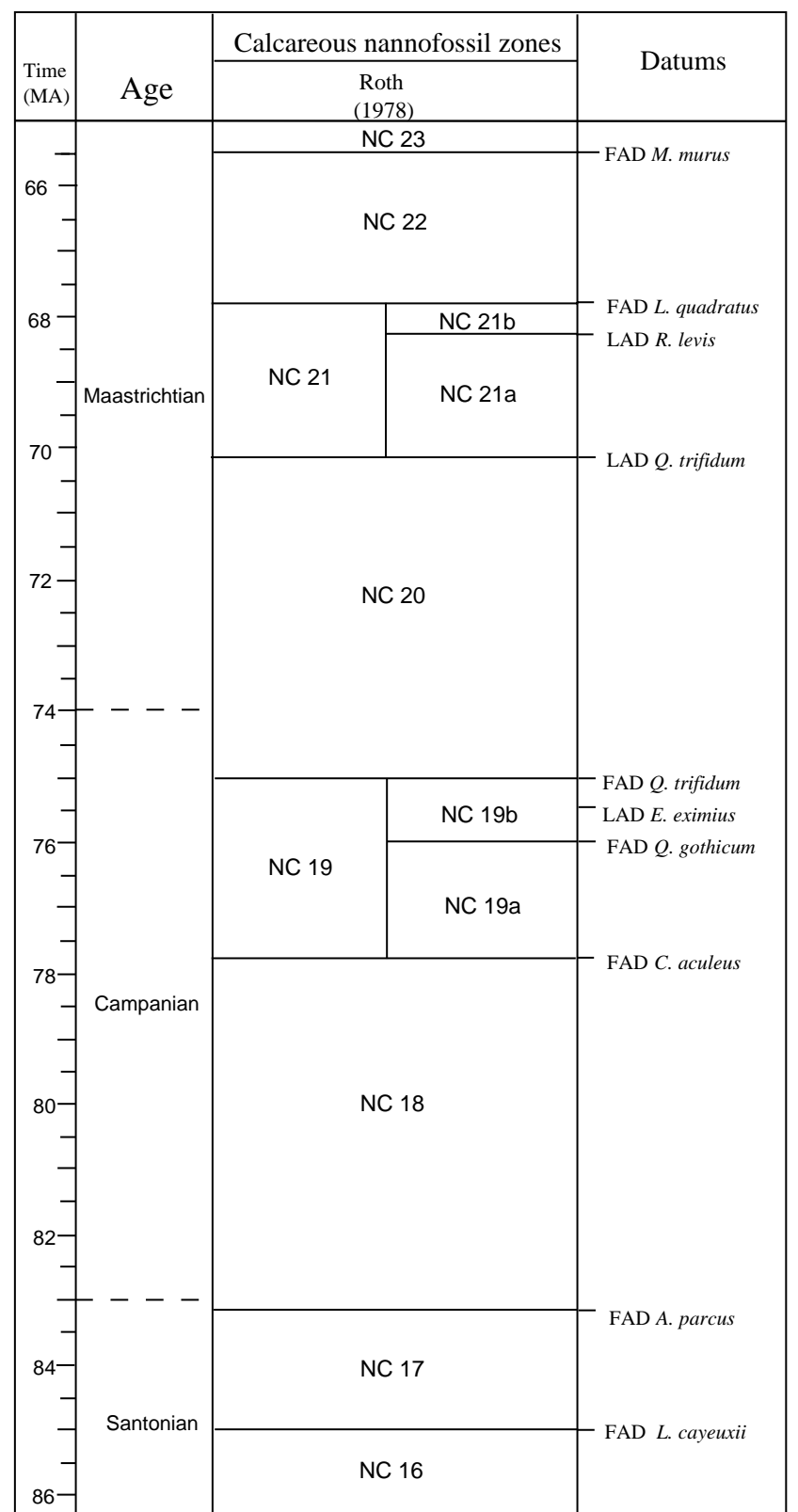

Figure 3. Time scale showing Maastrichtian through Santonian calcareous nannofossil events (Bralower et al., 1995). FAD = first appearance datum; $\mathrm{LAD}=$ last appearance datum.

pearance datums (LAD) of Toweius gammation and Discoaster lodoensis were observed. These collective ranges indicate that an unconformity may exist in the interval between 329.94 and 330.43 mbsf. Zone CP12 extends down to Sample 160-966F-31R-2, 24-25 $\mathrm{cm}$ (348.14 mbsf), below which a paucity of nannofossils prevents biostratigraphic interpretations.

\section{HOLE 967E}

Hole 967E is the deepest of six holes drilled along the northern base of the Eratosthenes Seamount. Hole 967E was washed down to a depth of $109.5 \mathrm{mbsf}$. In the first two cores below the washed interval, lower Pliocene ooze was recovered. In Core 160-967E-3H, the lithology changes where the ooze unconfomably overlies chalk that 
contains abundant middle Eocene nannofossils. A range chart of species observed within this interval is shown in Table 2.

In Samples 160-967E-3H-1, 46-47 cm (129.16 mbsf), through $4 \mathrm{H}-1,22-23 \mathrm{~cm}$ (138.52 mbsf), nannofossils indicative of Zone CP15 were observed. The typical assemblage from this interval includes rare occurrences of $C$. oamaruensis and abundant to common E. formosa, R. umbilicus, D. saipanensis, D. barbadiensis, Sphenolithus predistentus, and $H$. compacta. Similar to specimens observed from Hole 966F, the nannofossils from these samples in Hole 967E generally show fair preservation with heavy calcite overgrowths observed on thick-shielded taxa, such as the chiasmoliths.

Nannofossils assigned to Subzone CP14b were observed in sediments from Samples 160-967E-4H-1, 119-120 cm (139.39 mbsf), through 5H-2, 107-108 cm (150.51 mbsf). Samples from this interval lack $C$. solitus. Several events occur between Samples 160-967E$4 \mathrm{H}-2,35-36 \mathrm{~cm}$, and $4 \mathrm{H}-2,124-125 \mathrm{~cm}$, including the LAD of $C$. grandis, which may suggest an unconformity in this interval. The LAD $C$. grandis typically occurs just below the top of Subzone CP14b. Other events observed in Subzone CP14b include the FADs of Sphenolithus celsus, S. predistentus, and Reticulofenestra callida, and the LAD of Cribrocentrum coenurum.

Rare occurrences of $C$. solitus were first observed downhole in Sample 160-967E-5H-3, 17-18 cm (151.07 mbsf), which indicates that this sample is within Subzone CP14a. Other species observed in this sample and below include Helicosphaera wilcoxonii, Campylosphaera dela, and Sphenolithus obtusus.

Sample 160-967E-7R-1, 17-18 cm (167.47 mbsf), contains an assemblage that includes Toweius gammation and Chiasmolithus bidens. This sample is difficult to assign to a zone because of a lack of marker species. Tentatively, the sample is assigned to Zone CP12. The sample immediately below (Sample 160-967E-8R-2, 31-32 cm) is characterized by low abundance and diversity of nannofossils; therefore, it cannot be accurately assigned to a zone.

Beginning in Sample 160-967E-9R-1, 8-9 cm (186.58 mbsf), an Upper Cretaceous assemblage that includes Arkhangelskiella cymbiformis, Micula decussata, Lithraphidites carniolensis, Microrhabdulus decoratus, Cribrosphaerella ehrenbergii, Prediscosphaera cretacea, Watznaueria barnesae, and rare occurrences of Lithraphidites quadratus was observed (Table 3). Rare occurrences of a taxon identified as Micula murus were also noted, suggesting a tentative correlation to Maastrichtian Zone NC23. Preservation is poor to fair, and most robust species show severe overgrowths, all of which hinder identification.

In Samples 160-967E-9R-1, 125-126 cm (187.95 mbsf), through 10R-3, 22-23 cm (199.12 mbsf), the assemblage includes Lithraphidites quadratus in the absence $M$. murus. These samples are placed into Zone NC22.

Samples 160-967E-10R-3, 69-70 cm (199.59 mbsf), through 14R-2, 11-12 cm (236.31 mbsf), are assigned to Zone NC21. This interval is characterized by the lack of L. quadratus and the next zonal marker, Quadrum trifidum. Some researchers use the LAD of Reinhardtites levis to subdivide Zone NC21 into two subzones. In Hole $967 \mathrm{E}$, the LADs of $R$. levis and Q. trifidum occur in the same sample, which suggests a minor unconformity. The samples immediately above the unconformity are assigned to Subzone NC21b, whereas those samples below the unconformity are interpreted to be within Zone NC20.

Samples assigned to Zone NC20 were observed from Samples 160-967E-14R-2, 140-141 cm (237.60 mbsf), through 17R-2, 127$128 \mathrm{~cm}$ (266.17 mbsf). This zone is recognized by the presence of $Q$. trifidum, which occurs overgrown with calcite, but is nevertheless recognizable because of its distinctive triradiate morphology. Other species observed within this interval include Quadrum gothicum, $R$. levis, and rare occurrences of Reinhardtites anthophorus. The distinction between $R$. levis and $R$. anthophorus was difficult to determine in Hole 967E because of extensive overgrowth, which appear to fill the voids in the central area of the placolith and obscure the primary diagnostic feature that distinguishes the two species. Although it does not coincide with a nannofossil datum, the boundary between the Maastrichtian and the Campanian is located within Zone NC20.

Samples 160-967E-18R-1, 88-89 cm (273.98 mbsf), through 19R-1, 69-70 cm (283.39 mbsf) include $Q$. gothicum in the absence of $Q$. trifidum and are thus correlated to Subzone NC19b (Table 4). In the lowermost sample interpreted to be in Subzone NC19b (at $283.39 \mathrm{mbsf}$ ), the LAD of E. eximius, the FAD of $C$. aculeus, and the FAD of $Q$. gothicum are observed. Collectively, these data suggest that part of the zone below the LAD of E. eximius is absent at Hole 967E and represents an unconformity.

Below the unconformity, Samples 160-967E-20R-2, 31-32 cm (293.98 mbsf), through 24R-1, 56-57 cm (331.36 mbsf), include $A$. parcus and the absence of $C$. aculeus, which indicates that this interval is within Zone NC18. Based on these data, most of Zone NC18, all of Subzone NC19a, and possibly some of Subzone NC19b are represented by the unconformity. Although some of the missing interval may be the result of poor core recovery, the unconformity could represent as much as 7.5 m.y. of deposition at Site $967 \mathrm{E}$.

Samples 160-967E-25R-1, 41-42 cm (340.91 mbsf), through 29R-1, 41-42 cm (379.21 mbsf), contain L. cayeuxii in the absence of $A$. parcus, which results in a designation of Santonian Zone NC17. Lower in the zone, several species of Nannoconnus and Eprolithus floralis are observed. The base of Zone NC17 is marked by the FAD of $L$. cayeuxii.

The interval that includes Samples 160-967E-29R-2, 12-13 cm (380.42 mbsf), through 32R-1, 30-31 cm (408.00 mbsf), is tentatively placed in Zone NC16. This zonal interpretation is based on the absence of $L$. cayeuxii. However, several marker species that would typically be included in the assemblage are absent, which suggests that the samples below 380.42 mbsf could be older than Santonian. Missing from the assemblage in Samples 160-967E-29R-2, 12-13 $\mathrm{cm}$ (380.42 mbsf), through 32R-1, 30-31 cm (408.00 mbsf), are Ahmuellerella octoradiata, Kamptnerius magnificus, and Marthasterites furcatus. A paucity of nannofossils below $408.00 \mathrm{mbsf}$ prevent additional nannofossil interpretations.

\section{REFERENCES}

Berggren, W.A., Kent, D.V., Swisher, C.C., III, and Aubry, M.-P., 1995. A revised Cenozoic geochronology and chronostratigraphy. In Berggren, W.A., Kent, D.V., Aubry, M.-P., and Hardenbol, J. (Eds.), Geochronology, Time Scales and Global Stratigraphic Correlation. Spec. Publ.Soc. Econ. Paleontol. Mineral., 54:129-212.

Bralower, T.J., Leckie, R.M., Sliter, W.V., and Thierstein, H.R., 1995.An integrated Cretaceous microfossil biostratigraphy. In Scholle, P.A. (Ed.), Geochronology, Time Scales, and Global Stratigraphic Correlation. Spec. Publ.-Soc. Econ. Paleontol. Mineral., 54:65-79.

Emeis, K.-C., Robertson, A.H.F., Richter, C., et al., 1996. Proc. ODP, Init. Repts., 160: College Station, TX (Ocean Drilling Program).

Hay, W.W., 1970. Calcareous nannofossils from cores recovered on Leg 4. In Bader, R.G., Gerard, R.D., et al., Init. Repts. DSDP, 4: Washington (U.S. Govt. Printing Office), 455-501.

Martini, E., 1971. Standard Tertiary and Quaternary calcareous nannoplankton zonation. In Farinacci, A. (Ed.), Proc. 2nd Int. Conf. Planktonic Microfossils Roma: Rome (Ed. Tecnosci.), 2:739-785.

Moshkovitz, S., 1984. Late Cretaceous calcareous nannofossil biostratigraphy of the Mount Scopus Group. Isr. Geol. Surv. Curr. Res., 19831984:46-48.

Okada, H., and Bukry, D., 1980. Supplementary modification and introduction of code numbers to the low-latitude coccolith biostratigraphic zonation (Bukry, 1973; 1975). Mar. Micropaleontol., 5:321-325.

Roth, P.H., 1978. Cretaceous nannoplankton biostratigraphy and oceanography of the northwestern Atlantic Ocean. In Benson, W.E., Sheridan, R.E., et al., Init. Repts. DSDP, 44: Washington (U.S. Govt. Printing Office), 731-759.

Date of initial receipt: 23 February 1997

Date of acceptance: 19 June 1997

Ms 160SR-070 


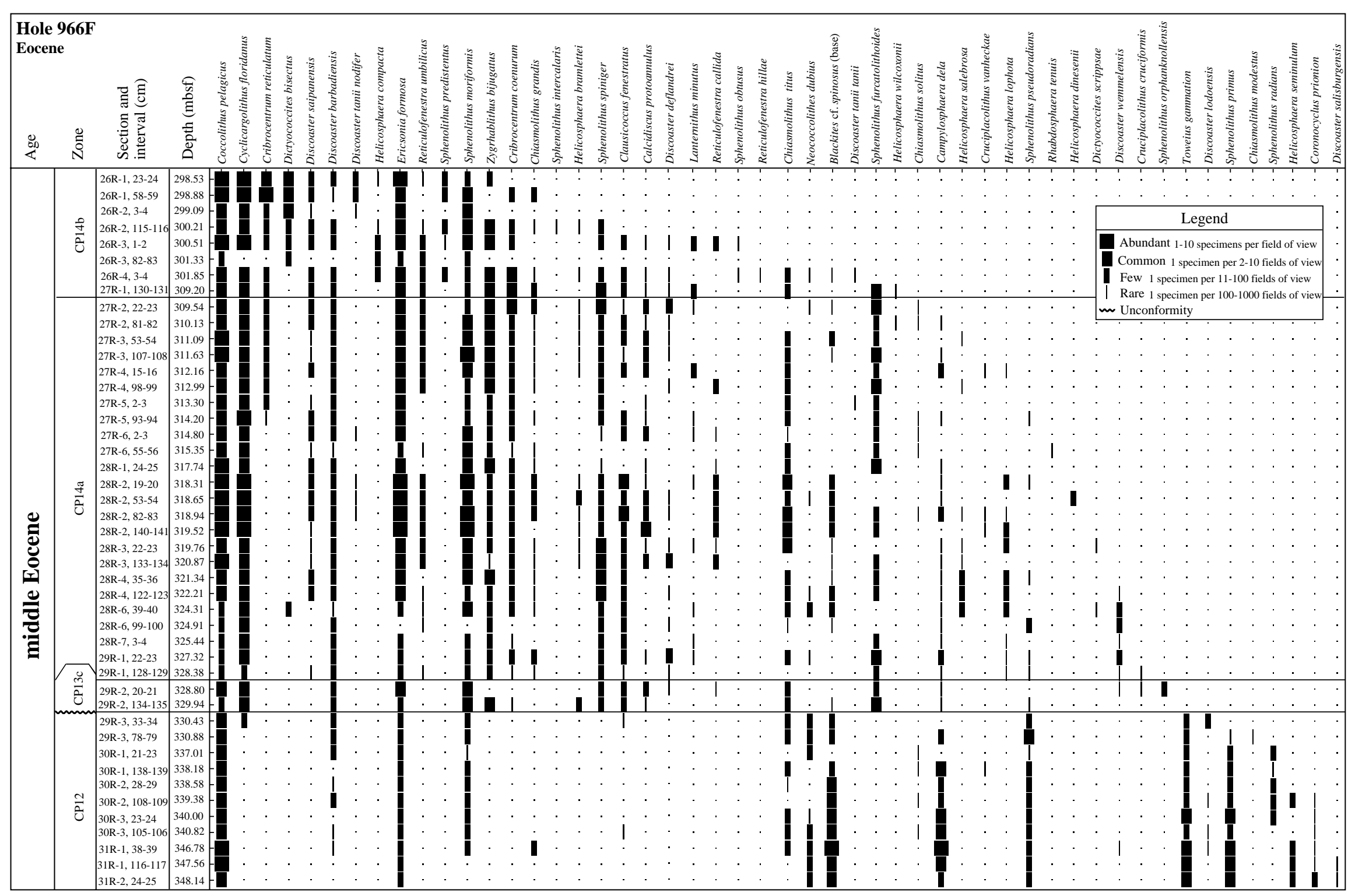


Table 2. Calcareous nannofossil range chart and biostratigraphic interpretation for Eocene chalks sampled from Hole 967E.

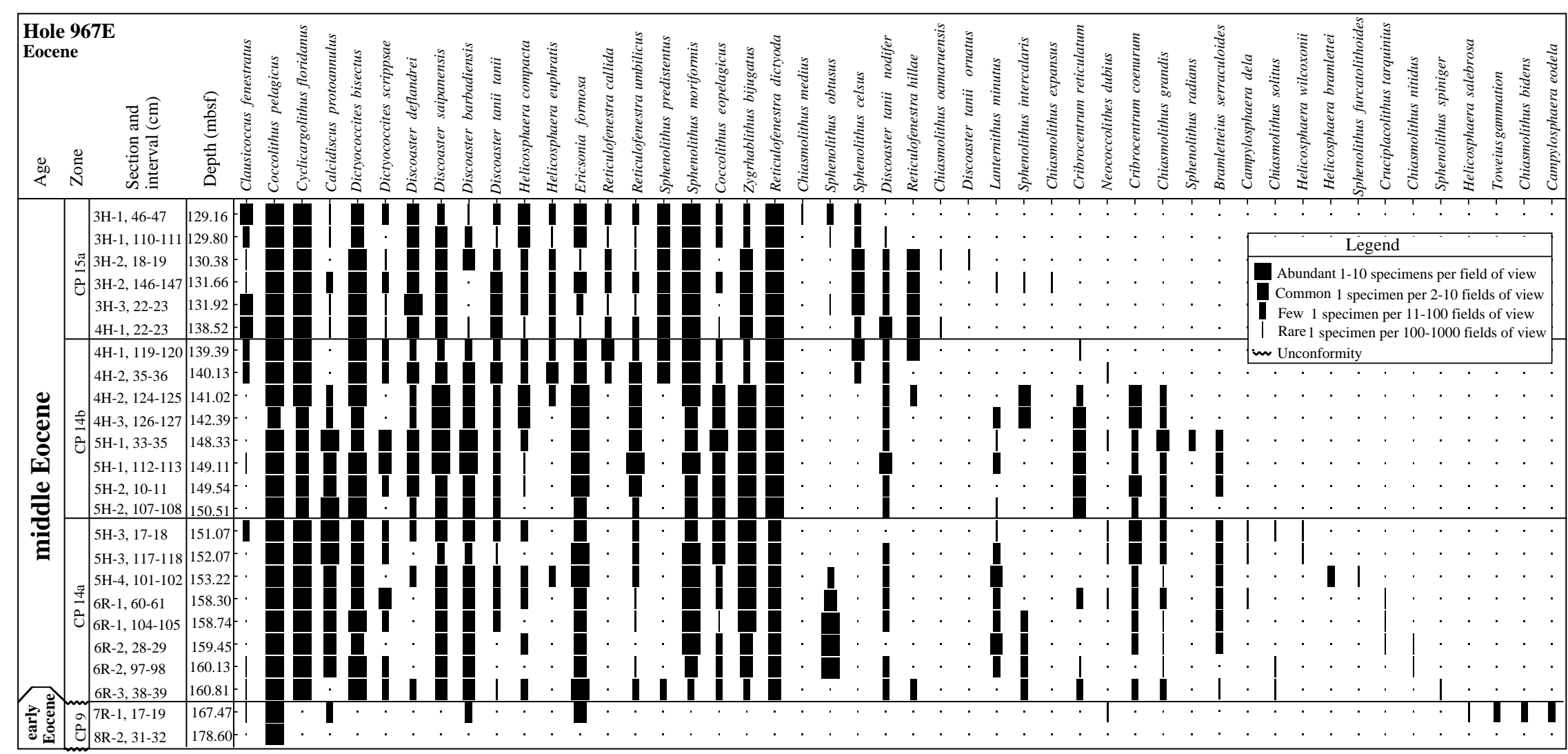




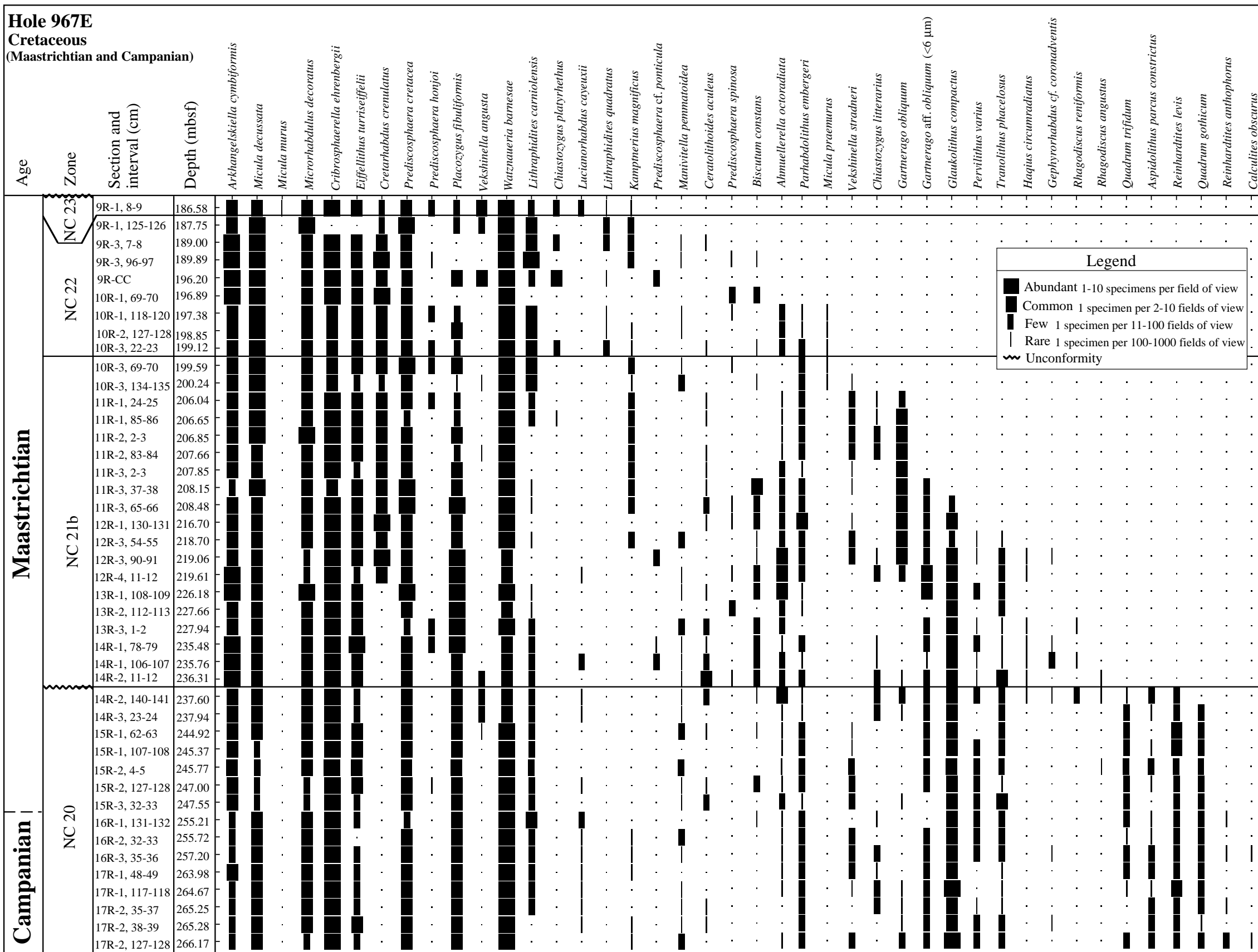


Table 4. Calcareous nannofossil range chart and biostratigraphic interpretation for Cretaceous (Campanian and Santonian) chalk sampled from Hole 967E.

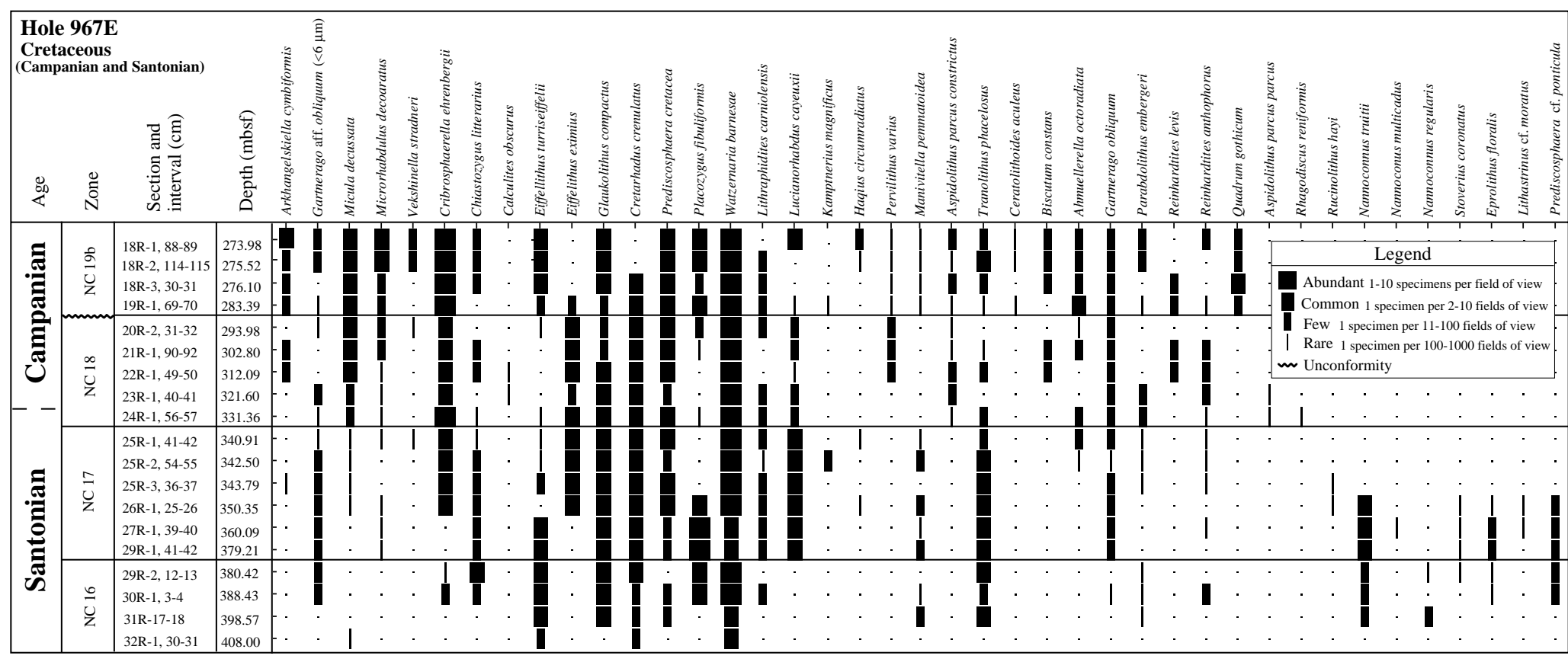

